\title{
Optimization of Factorial Portfolio of Trade Enterprises in the Conditions of the Non-Payment Crisis
}

\author{
Svetlana NESTERENKO${ }^{1}$, Svetlana DROBYAZKO², Olha ABRAMOVA ${ }^{3}$, \\ And Natalya SIKETINA ${ }^{4}$
}

\author{
1,2Open international University of human development "Ukraine", Kyiv, Ukraine \\ ${ }^{3}$ Kharkiv Educational and Scientific Institute of SHEI "Banking University", Kharkiv, Ukraine \\ ${ }^{4}$ National Technical University "Kharkiv Polytechnic Institute", Kharkiv, Ukraine
}

Correspondence should be addressed to: Svetlana NESTERENKO; svetlana.drobyazko@yahoo.com

Received date:22 April 2019; Accepted date:16 July 2019; Published date: 29 August 2019

Copyright (C) 2019. Svetlana NESTERENKO, Svetlana DROBYAZKO, Olha ABRAMOVA, And Natalya SIKETINA. Distributed under Creative Commons CC-BY 4.0

\begin{abstract}
The economic mechanism for factoring management of trade enterprises was improved by applying a tool for refinancing receivables involving third parties, which will contribute to the effective management of fundraising processes from the standpoint of the income approach. The instruments for the implementation of the economic mechanism of factoring management of commercial enterprises, consisting of five blocks were improved (analysis of commercial enterprise debtors' solvency in order to transfer them to factoring services; analysis of accounts receivable and assessment of its real value; planning of cash flows from factoring operations; factoring implementation assessment; monitoring and control of the repayment of receivables in the process of factoring services), that allows substantiating practical recommendations for improving the level of factoring management. Based on the concept of a portfolio of investments, a factoring model was built to optimize the debtors of the enterprise.
\end{abstract}

Keywords: accounts receivable, refinancing, factoring, debtor portfolio, optimization

Cite this Article as: Svetlana NESTERENKO, Svetlana DROBYAZKO, Olha ABRAMOVA, And Natalya SIKETINA. (2019)," Optimization of Factorial Portfolio of Trade Enterprises in the Conditions of the Non-Payment Crisis", IBIMA Business Review, Vol. 2019 (2019), Article ID 278890, DOI: 10.5171/2019.278890 


\section{Introduction}

In the modern conditions of the global economy, the deepening of inflation processes and the growth of economic instability, commercial enterprises are increasingly faced with the problem of nonpayment or late payments of their debtors. The result of this problem in the enterprise is the growth of accounts receivable and the shortage of working capital, which affects the slowdown of its economic development.

The lack of working capital to finance the main activities of business entities has necessitated the search for and use of effective instruments for managing receivables, to ensure regular cash flows to finance the business. One of the modern financial market instruments capable of providing regular cash flows to finance a business is factoring.

World practice shows an increase in the volume of factoring operations, which indicates its popularity. The use of factoring allows not only increasing sales, liquidity and profitability of enterprises, but also has a positive effect on the economic development of the country.

In view of this, it is essential to use reliable, high-quality and adequate information about the debt, which is formed in the accounting system (Hilorme, T., Perevozova, I., Shpak, L., Mokhnenko, A. \& Korovchuk, Yu. (2019), Drobyazko, S., Hryhoruk, I., Pavlova, H., Volchanska, L., \& Sergiychuk, S. (2019)). Thus, the introduction of modern methods of receivables management, such as factoring, insurance of financial risks, the use of bills for payment allows optimizing the debt of the enterprise.

\section{Literature Survey}

Despite the presence of a large number of scientific works in the field of factoring services without reducing the value of scientists' research, the issues of the effectiveness of factoring in the activities of trade enterprises taking into account the basic methods and indicators remained unresolved.

Forman M., Gilbert J. (1976), F. Salinger (1999), Bickers M. (2003) consider factoring as an integrated service that includes not only financing, but also administration of debit indebtedness, credit risks insurance, etc. Such an interpretation foremost truly characterizes the factoring essence. With the help of factoring services on deferred payment terms, sales of products are rapidly increasing. In addition, in case of the rational desired expenditure this service allows manufacturers not to have a shortage of working capital when working on deferred payment terms.

It should be noted that today, the economically developed countries of the world are mastering new types of factoring services, such as reverse, procurement factoring, financing for goods, etc. (Ash, A. L. (2017)). Such types of factoring services differ from the classical factoring mechanism of the implementation of factoring operations. Thus, in case of reverse or procurement factoring, factoring service is initiated by an enterprise-buyer, instead of an enterprise-supplier.

\section{Methods}

In the process of study, general scientific and special methods of scientific knowledge were used, namely: critical analysis, scientific abstraction and generalization of the scientific experience of modern theoretical studies (in determining directions for improving the conceptual apparatus, studying the theoretical foundations and scientific approaches to the factoring management process); structural and dynamic analysis (in the study of the financial condition of trade enterprises); coefficient method (when justifying the economic feasibility of factoring in the activities of commercial enterprises); diversification method (in the formation of the factoring portfolio of commercial enterprises). 
Methodological platform for forming a model of factoring choice is portfolio investing models - Modern portfolio theory (Markowitz H. (1952)) and price model of capital market CAMP. Sharpe W.F. (1964) while developing CAMP determined the assumption of the portfolio formation. The analysis of factoring peculiarities allows defining adapted assumptions for factoring portfolio optimization, namely: it defined for factoring agreement after detailed analysis such conditions as:

1. Enterprise's debtors should not be dependent - the factor, as a rule, checks for the presence of affiliated persons. Affiliated persons should not be included in the factoring portfolio.

2. The assessment of the factoring portfolio is determined on the basis of two factors: the operation profitability and the risk level.

3. When choosing several factoring portfolios, an enterprise should choose a portfolio with maximum profitability.

4. An enterprise wants to reduce risks, that is, it chooses a portfolio with the lowest risk (according to Sharpe, - standard deviation).

5. Factors determine the factoring limits, that is, an enterprise may be not fully financed in limit, but choose only its part, or the factor itself can reduce it if necessary.

6. In order to determine the validity of the factoring limit, the enterprise should determine its expediency of the supply turnover in the monthly section.

\section{Results}

Today, the problem of providing enterprises with working capital is a priority, given their decisive role in the process of both production and trade cycles.
In order to improve the work of the enterprise and increase the economic profit, it must compare the actual availability of working capital with the norm, which allows determining the shortage or surplus of its working capital.

The surplus of working capital may arise due to over fulfilment of the profit plan, the incomplete contribution of payments to the budget, incomplete receipt of commodity stocks and supplies from other organizations, incomplete use of profit for the purposes stipulated by the financial plan etc.

On the basis of the discrete price model of the capital market, we will create conditions for a factoring agreement - a list of debtors 1, .., $n$ (A. V. Myshchenko, Ye. V. Vynohradova (2013)). At the same time, the delay of payment (according to the contracts of wholesale enterprises) for the i-th debtor is 60 calendar days from the date of goods delivery. We will indicate this delay as $k_{i}$. In accordance with the enterprise`s assets profitability theory, the financing agent (Factor), in keeping with the agreement, may grant an additional deferment to for client's (delay up to 30 calendar days (r)). The enterprise wanted to get in defined moment $t_{i}$ profit for each factoring $k_{i}$ of each $i^{\text {th }}$ debtor, defined by such a distribution of factoring service price, which will be paid by the enterprise to Factor $-\gamma_{i}^{1}, \ldots, \gamma_{i}^{m}$ with a probability of $p_{i}, \ldots, p_{m}$. Also, for the engagement factor of engagement financial resources on the market $-\alpha_{i}$. Herewith $\gamma_{i}$ - is the amount of the net profit rate of the Factor (d) and $s_{i}$ - variable component of the Factor`s profit, type which is determined in factoring agreement, and the current value is fixing by each financing. 
When $d=0$, the rate for для market participant will be drifting, when $s_{i}=0$, the rate becomes fixed (Roll R.J., Ross S.A. (1980)).
Mathematical expectation of the expenses to financing operation is as follows:

$$
\bar{\gamma}_{i}=\sum_{j=1}^{m}\left(d+s_{i}^{j}\right) \times p_{i}
$$

It is also necessary to determine $\beta$ coefficient to each debtor, indicated as $\beta_{i}(i=1,2, \ldots, n)$. Such coefficients determine quantitative estimate for each debtor. For the calculation of risk coefficients $\beta$ we propose to construct matrix of risk coefficients when debtors analyzing in accordance with the Matrix of customers categories on the results of $X Y Z$ and $A B C$ analyses.

Table 1: Matrix of customers categories on the results of XYZ and ABC analyses

\begin{tabular}{|l|c|c|c|}
\hline $\begin{array}{l}\text { Payment discipline } \\
\text { of the } \\
\text { counterparties }\end{array}$ & Good & Medium & Satisfactory \\
\cline { 1 - 1 } $\begin{array}{l}\text { Profit from lending } \\
\text { operations with } \\
\text { counterparties }\end{array}$ & 0 & $0,02-0,2$ & $0,21-0,5$ \\
\hline Good & $0,01-0,2$ & $0,21-0,5$ & $0,51-1,0$ \\
\hline Medium & $0,21-0,5$ & $0,51-1,0$ & 1,0 \\
\hline Satisfactory & & & \\
\hline
\end{tabular}

In the current financing limit (F) factor wants to include into factoring portfolio only those debtors, who allow at the time moment $t_{i}$, increasing its profitability $\Delta F$.

The factor as an enterprise, on the basis of the principles of Unit 1 of the management model of the debtors management of debit indebtedness of the enterprises, considered earlier, on the basis of the analysis of financial statements of each debtor, determines the sublimit of financing $V_{i}$.

Herewith a condition of factoring limit exists as an amount of factoring sublimits:

$$
V_{1}+V_{2}+\ldots+V_{n}=F
$$

Let's assume, that $i$ - th debtor has $k_{i}$ delay, that is, debtor 1 has the payment of the delay $k_{2}, 2^{\text {th }}$ debtor $-k_{3}$, and the debtor $n$ has the delay $k_{n}$. In this way, deliveries sales by the debtor $O_{i}, \ldots, O_{n}$ (according to the delivery statistics of the wholesale enterprises).

In the first case the limit (when minimal risk) for an enterprise will be equal to $O_{1} \times n$, and in the second case (when maximal risk) - 
$O_{n} \times n$. Nonetheless for the enterprise the most effective is the medium limit value:
$\bar{O}_{i} \times n$. It is also possible to use formula for financing limit determining:

$$
\sum_{i=1}^{n} O_{i} \times \frac{t_{\max }}{t_{i}}
$$

Considering the bove introduced definitions, lets form the factoring portfolio task:

$$
\begin{aligned}
& \sum_{i=1}^{n} V_{i} x_{i}\left(\bar{\gamma}_{i}-\alpha_{i}\right) \rightarrow \min , \\
& \sum_{i=1}^{n} V_{i} x_{i} \leq F, \\
& \sum_{i=1}^{n} V_{i} x_{i} \alpha_{i} \frac{\beta_{i}}{F} \leq \beta_{\max }, \\
& x_{i} \in\{0,1\}, i=1,2, \ldots, n .
\end{aligned}
$$

$\beta_{\max }$ defines the maximum permitted value of the whole factoring portfolio, the level of which is determined by the factor itself.

Then the target function of the factoring portfolio analytically looks like:

$$
\sum_{i=1}^{n} V_{i} x_{i}\left(\sum_{j=1}^{m}\left(d+s_{i}^{j}\right) p_{j}-\alpha_{i}\right) \rightarrow \min
$$

Herewith the minimization of the target function will increase the income received by the enterprise in factoring at the expense of reducing costs - the factor payment for the transaction. This formula is used while invoice-discounting. Whereas in full factoring

$$
\sum_{i=1}^{n} V_{i} x_{i}\left(\sum_{j=1}^{m}\left(d+s_{i}^{j}\right) p_{j}-\alpha_{i}\right)+\sum_{i=1}^{n} V_{i} f_{i} \rightarrow \min
$$


After construction of the matrix of buyers categories according to the results of $X Y Z$ and $A B C$ analysis, it is determined that the debtors $A Z, B Z, C Z$ should apply factoring. For the factoring portfolio optimization, we will determine such debtors through the variables $x_{1}-x_{13}$. These variables will indicate whether the total factoring portfolio is added to the debtor or not. If $x$ equals to 0 , the debtor is excluded from the Factoring portfolio, if $x$ equals to 1 - the debtor is included to the factoring portfolio.

The target function of the task is solved with the help of the predefined function of Excel «Search for solution». One of such ITproducts is a procedure «Solver», which is included in the standard completing of the program Microsoft Excel and which is an automation system for choosing the optimal solution. «Solver» is a program softwareoriented add-on, written in programming language Visual Basic. The module allows entering a large number of constraints and different conditions for choosing the optimal solution for task purpose task and is suitable for use in enterprises, banks and factoring companies, since it does not require additional financial costs for its acquisition, it is very easy to use, does not require special training, as well as there is a special technical requirement for the equipment, because Excel can be installed on any computer. The only thing that will have to spend time on financial analysts is to enter data, for example, entering data limitations for about 100 debtors may take more than two hours.

After eliminating the riskiest debtors from the factoring portfolio, solving the discrete and continuous tasks of linear programming, it is possible to obtain information for making managerial decisions on the effectiveness of factoring.

The factoring portfolio without the participation of the riskiest debtors did not become less effective in terms of return: with integer constraints, the annual income of a factor from the conclusion of a factoring contract is reduced by 4963,68 dollars., which is not a significant indicator, given that the transaction risk is 0.0001; under continuous constraints, the company's income will remain the same as when it comes to the portfolio of buyers with the highest risk, but at the same time, the overall portfolio risk is reduced to 0,0010 .

The assessment of the possibility of a factoring transaction is an integral part of the organizational and economic mechanism for managing the factoring of trading enterprises, which in our opinion consists of 5 blocks.

The results of the first block "Analysis of the Possibility of Including Debtors of the Enterprise to Conduct Factoring" are: solvency analysis of debtors; exclusion from the list of debtors with a high level of risk of non-repayment of debts, expansion of consumer circles, the formation of individual conditions for the provision of commercial loans, etc. In Block II "Planning Cash Flows Based on Collection Ratios" a company's payment policy is created (in our opinion, it is possible to use the cash optimization models of Baumol and Miller-Or. Block III "Conduct Analysis of Accounts Receivable and Estimation of Its Real Value" includes the following elements: determination of the actual amount of receivables of each debtor; definition of the nature and pay-back period; analysis of receivables by types of products; determination of overdue debt, analysis in the dynamics of the indebtedness period. Block IV "Estimation of the Factoring Opportunity and Its Implementation". Determination of the need to use factoring as a variant of repayment receivables with the involvement of a third party is possible with the use of factoring portfolio optimization. Block V.: "Control Over Repayment of Accounts Receivable" includes the following components: analysis of the efficiency of methods of debt repayment (factoring, cash payments, barter, netting, promissory notes, etc.); conducting negotiations in terms of repayment of accounts receivable, forming a 
system of fines, involvement of the debtor in the conduct of bankruptcy proceedings, etc.

When forming complete, reliable and relevant management information for the segment of settlements with counterparties management accounting tools are required (Hilorme, T., Shurpenkova, R., KundryaVysotska, O., Sarakhman, O., \& Lyzunova, 0. (2019)). When choosing a factor, trade enterprises focus their attention on the basic conditions of a factoring agreement, specifically: limit and amount of financing, the term of financing and commission (Hawley, J. P., \& Lukomnik, J. (2018)). For enterprises, it is important that the limit and the period of financing would be the maximum, and the size of the commission the minimum. The next stage after choosing the factor is the signing of the factoring agreement. Wholesale companies are the initiators of signing a classic factoring agreement. If the initiator of the signing of the factoring contract is a buyer, that is, a retail enterprise, then a trilateral reverse factoring agreement is concluded. (Kai, M. A., et al. (2017)).

Factoring as an option for repayment of receivables with the involvement of a third party should be managed, and there are two main approaches: Unprofitable (criterion cost minimization) and profitable (criterion maximization of profit). All these approaches are taken from the enterprise asset management theory.

In practice, the application of approaches to the management of factoring in its pure form is impractical - effective management should take into account the maximum number of factors, the consequences of management and contribute to the achievement of management tasks. For this reason, the most universal and desirable, in our view, is a profitable approach to managing factoring of an enterprise, with a profit-oriented approach to achieving a long-term effect
(Kim, Y. (2017), Lai, J., Wang, H. H., Ortega, D. L., \& Widmar, N. J. O. (2018)).

Considering the above, we can say that factoring as a tool for financing working capital allows an enterprise: to minimize the receivables, turning them into working capital and transfer the costs of financing its working capital to its debtors.

This possibility arises as a result of the fact that the Factor customer, receiving a significant part of the amount of delivery on the day of delivery, and thereby losing its dependence on compliance with its debtors of payment discipline, can shorten the termination of payment when purchasing goods and demand from their suppliers the best price conditions for the procured goods. In addition, it receives a guarantee of protection against fines from creditors on late settlements with them caused by a cash gap.

Differences in the development of factoring in developing countries and in those that are already economically developed should be noted. In developing countries, invoice discounts are used the most, while developed countries offer fundamentally new factoring services such as reverse factoring, financing for goods, equipment, etc. Factoring companies in developed countries are expanding the network of foreign affiliates and subsidiaries developing their activities through the Internet. A greater role is assigned to risk management and administration of receivables, and not just its financing.

The development of factoring will contribute to economic growth since it provides a higher level of solvency of enterprises and an increase in sales due to the possibility of postponement of payment. 


\section{Discussion}

If one approach the decision of continuous task of liner programming without debtors taking part in it with high risk rates, then, at first sight, the decision that you get looks completely acceptable and the most remunerative for enterprise due to that the annual income of enterprise will remain the same and the risk of factoring portfolio will reduce for the client from 0,0012 to 0,0010 . However, the limits under such conditions should be chosen in such small proportions that it simply does not seem reasonable from the practical point of view, and neither the enterprise, in the first place, nor the factor will go to the conclusion of this factoring operation with such mathematically grounded and understandable data, but practically not feasible and not appropriate conditions for their realization in real conditions (Hilorme, T., Zamazii, O., Judina, O., Korolenko, R. \& Melnikova, Yu. (2019)).

In the activities of trading enterprises, there are problems associated with the postponement of payments, the growth of turnover in the season of growing demand for goods, without waiting for delays payments from buyers. At present, there are various forms of the refinancing of accounts receivable, that is, its rapid transfer to other forms of current assets (cash or highly liquid securities).

It has been proved that factoring is one of such promising forms of the refinancing of accounts receivable on the financial market of Ukraine and a financial instrument that gives the opportunity to replenish working assets of trading enterprises as quickly as possible.

The main function of factoring is to reduce non-payments, to accelerate the flow of goods, and to create a stable system of financial support for enterprises.

The use of factoring enables supplier companies to reduce the turnaround time for receivables, thereby turning them into cash and investing them in economic activities, which will have a positive effect on the financial results of the enterprise and the development of the economy as a whole.

It is substantiated that factoring is a particularly beneficial form of financing for trading companies, which enables managers and employees to concentrate on production problems and maximize profits. It accelerates the receipt of most of the payments, guarantees full repayment of debts and reduces the cost of maintaining accounts. Factoring provides a guarantee of payment and saves suppliers from having to take additional and very expensive loans from a bank. All this has a beneficial effect on the financial situation of enterprises.

\section{Conclusion}

If an enterprise uses factoring services, it can significantly reduce the selling price of the product when sold with a delay in payment. At first glance, this seems paradoxical, because it will have to pay an additional commission to the agent. In fact, there is no paradox here. Feeling shortage of working capital, the supplier could himself establish a sale of goods with a delay in payment of the markup higher than the one that will be required to pay in the form of commission in the factoring transaction. In addition, if the commodity has a currency component, then, setting the price in hryvnias, the supplier was forced to ensure against a sharp change in the dollar or the euro. In factoring service, the company removes currency risk and it is not necessary to bring in the price of the goods, the risk of non-payment of delivery in time.

The development of factoring will contribute to the emergence of domestic enterprises from the crisis situation and their economic development, as it will provide a higher level of solvency of enterprises and increase sales through the possibility of postponement of payment. 
It is worth pointing out that factoring as a financial instrument has more advantages than disadvantages, especially for trading companies, where the question of the sufficiency of working capital and sales is particularly relevant. Today, most of these enterprises are solving the dilemma: or attracting new customers, stimulating their favourable terms of commodity credit, or maintaining working capital at the proper level. In this situation, factoring can be the best solution to this problem.

\section{References}

1. Armsworth, P. R., Jackson, H. B., Cho, S. H., Clark, M., Fargione, J. E., Iacona, G. D., ... \& Sutton, N. A. (2017). Factoring economic costs into conservation planning may not improve agreement over priorities for protection. Nature communications, 8(1), 2253. https://doi.org/10.1111/ele.12230

2. Ash, A. L. (2017). It's Your Money and We Want It Now: Regulation of the Structured Settlement Factoring Industry in the Era of Dodd-Frank and the Consumer Financial Protection Bureau. Miss. LJ, 86, 151. URL: https://heinonline.org/HOL/LandingPage?h andle $=$ hein.journals $/$ mislj86 \&div $=8 \& i d=\& p a$ ge $=$

3. Bunich, G. A., Rovenskiy, Y. A., \& Dashkov, L. P. (2018). Factoring development: Theory and practice. Espacios, 39(19), 17 p. URL: http://www.revistaespacios.com/a18v39n1 9/a18v39n19p33.pdf

4. Guerard, J. B., Markowitz, H., Xu, G., \& Wang, Z. (2018). Global portfolio construction with emphasis on conflicting corporate strategies to maximize stockholder wealth. Annals of Operations Research, 267(1-2), 203-219. URL: https://doi.org/10.1007/s10479-016-2380$\underline{4}$
5. Drobyazko, S., Hryhoruk, I., Pavlova, H., Volchanska, L., \& Sergiychuk, S. (2019). Entrepreneurship Innovation Model for Telecommunications Enterprises. Volume 22, Issue 2 2, 2019. URL: https://www.abacademies.org/articles/entr epreneurship-innovation-model-fortelecommunications-enterprises-8097.html

6. Hawley, J. P., \& Lukomnik, J. (2018). The Third, System Stage of Corporate Governance: Why Institutional Investors Need to Move Beyond Modern Portfolio Theory.

URL: https://papers.ssrn.com/sol3/papers.cfm?ab stract_id $=3127767$

7. Hilorme, T., Perevozova, I., Shpak, L., Mokhnenko, A. \& Korovchuk, Yu. (2019). Human Capital Cost Accounting in the Company Management System. Academy of Accounting and Financial Studies Journal. Volume 23, Special Issue 2, 2019. URL: https://www.abacademies.org/articles/Hum an-Capital-Cost-Accounting-in-the-CompanyManagement-System-1528-2635-23-SI-2415.pdf

8. Hilorme, T., Shurpenkova, R., KundryaVysotska, O., Sarakhman, O., \& Lyzunova, 0. (2019). Model of energy saving forecasting in entrepreneurship. Journal of Entrepreneurship Education. Volume 22, Special Issue $1 S$. URL: https://www.abacademies.org/articles/mod el-of-energy-saving-forecasting-inentrepreneurship-7994.html

9. Hilorme, T., Zamazii, O., Judina, O., Korolenko, R. \& Melnikova, Yu. (2019). Formation of risk mitigating strategies for the implementation of projects of energy saving technologies. Academy of Strategic Management Journal. Volume 18, Issue 3. URL: https://www.abacademies.org/articles/For mation-of-risk-mitigating-strategies-for-theimplementation-of-projects-1939-6104-183-364.pdf

Svetlana NESTERENKO, Svetlana DROBYAZKO, Olha ABRAMOVA, And Natalya SIKETINA (2019), IBIMA Business Review, DOI: 10.5171/2019.278890 
10.Kai, M. A., Rui, M. I. A. O., YANG, W. C., Zhou, P. E. N. G., Bowen, S. U. N., \& HU, N. Y. (2017). A management method of accounts receivable based on credit rating for rail equipment manufacturing industry. In Proceedings of the 23rd International Conference on Industrial Engineering and Engineering Management 2016 (pp. 227231). Atlantis Press, Paris. URL: https://doi.org/10.1016/j.foodcont.2017.09. 032

11.Kim, Y. (2017). Consumer responses to the food industry's proactive and passive environmental CSR, factoring in price as CSR tradeoff. Journal of business ethics, 140(2), 307-321.

URL: https://doi.org/10.15678/EBER.2018.06010 2

12.Lai, J., Wang, H. H., Ortega, D. L., \& Widmar, N. J. O. (2018). Factoring Chinese consumers' risk perceptions into their willingness to pay for pork safety, environmental stewardship, and animal welfare. Food Control, 85, 423-431. URL: https://www.sciencedirect.com/science/arti cle/pii/S0956713517304668

13. Mishchenko, A., Vinogradova E. (2013). Optimization models for managing financial resources of an enterprise. RIOR: INFRA-M, 337

p.

URL: http://znanium.com/spec/catalog/author/?i $\mathrm{d}=12 \mathrm{fdb} 6 \mathrm{dc}-\mathrm{efac}-11 \mathrm{e} 3-9244-90 \mathrm{~b} 11 \mathrm{c} 31 \mathrm{de} 4 \mathrm{c}$

14.Sharpe, W. (2017). Capital Market Theory, Efficiency, and Imperfections. Quantitative Financial Analytics: The Path to Investment Profits, $445 . \quad$ URL: https://books.google.com.ua/books?hl=uk\&l $\mathrm{r}=$ \&id=Gcw5DwAAQBAJ\&oi=fnd\&pg=PA445 $\& d q=2 . \% 09$ Sharpe,$+W .+(1964) .+$ Capital + Ass et+Prices:+Theory+of+Market+Equilibrium+ under+Conditions+of+Risk\&ots=M5ANhddT e1\&sig=Jbc---

JHTb1jNxMo3r18PoECxDQ\&redir_esc $=y \# v=0$ nepage $\& \mathrm{q} \& \mathrm{f}=$ false

15.Xu, B., Zhao, J., Zheng, T., Litvinov, E., \& Kirschen, D. S. (2018). Factoring the cycle aging cost of batteries participating in electricity markets. IEEE Transactions on Power Systems, 33(2), 2248-2259. URL: https://doi.org/10.1109/TPWRS.2017.2733 339

16.Roll R.J., Ross S.A. An Emperical // Journal of Finance Vol. XXXXV, No. 5, December 1980. 17.Salinger $F$. Factoring. The Law and Practice of Invoice Finance. London. Sweet\&Maxwell - 1999. - 425 p.

18.Sharpe W.F. Capital Asset Prices: Theory of Market Equilibrium under Conditions of Risk // Journal of Finance/ Issue 3 (September 1964).

Svetlana NESTERENKO, Svetlana DROBYAZKO, Olha ABRAMOVA, And Natalya SIKETINA (2019), IBIMA Business Review , DOI: 10.5171/2019.278890 